\title{
New Literature
}

(A selection from Nordicom's database NCOM) 


\section{Denmark \\ Documentalist: Mogens Vestergaard Kjeldsen}

\section{Accessible Radio}

Archive, accessibility and materiality in the youth radio programme $\mathrm{P} 4$ i P1

Mette Simonsen Abildgaard, 2014. 198 s. Ph.d.-afhandling.

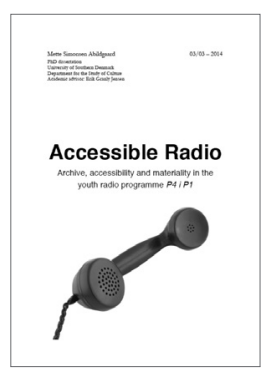

This anthological PhD dissertation is an examination of the development of listeners' involvement and technology in the youth radio programme $\mathrm{P} 4$ i P1 from 1973 to 1996. At its beginning in 1973, P4 i P1 was an innovative example of youth radio and especially experimented with the listener involving radio genres, which in the dissertation are termed 'accessible radio'.

\section{Analyzing Music in Advertising}

Television commercials and consumer choice

Nicolai Jørgensgaard Graakjær, Routledge, 2014. 200 s. ISBN 978-1138781085.

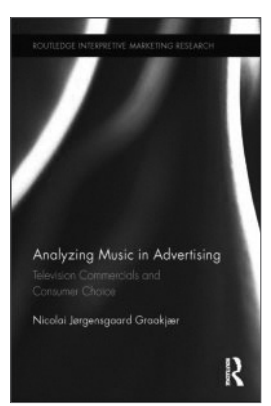

The study of music in commercials is well-suited for exploring the persuasive impact that music has beyond the ability to entertain, edify, and purify its audience. This book focuses on music in commercials from an interpretive text analytical perspective, answering hitherto neglected questions: What char$\mathbf{R}$ acterizes music in commercials compared to other commercial music and other music on TV? How does music in commercials relate to music 'outside' the universe of commercials? How and what can music in commercials signify?

\section{Infostorms}

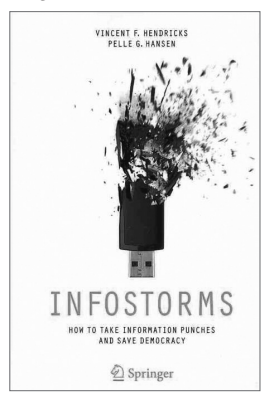

How to Take Information Punches and Save Democracy

Vincent F. Hendricks \& Pelle Guldborg Hansen, New York: Springer Science+Business Media B.V., 2014. 160 s. ISBN 978-3319038315.

This detailed guide to navigating the bewildering superabundance of information in today's globalizing world draws on the latest work in philosophy and the social sciences to explore how information, and its misuse, can both support and undermine democracy.

\section{Cosmopolitanism and the New News Media}

Chouliaraki Lilie \& Bolette Blaagaard (eds.), Routledge, 2014. 135 s. ISBN 978-0415734899.

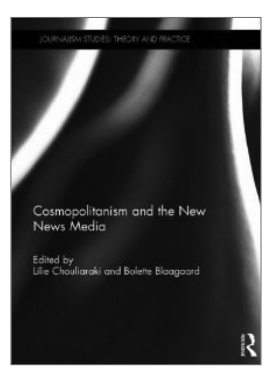

Some celebrate the power of new media to transform journalism as a new cosmopolitanism that challenges the traditional boundaries of foreign reporting, yet others fear that the new media simply reproduce old power relations in new ways. It is this important controversy around the role of new media in shaping a cosmopolitan journalism that offers the starting point of this book. By bringing together a range of theorists in the field of journalism and media studies, this collection insightfully explores how Twitter, Facebook, Flickr and YouTube are taking the voice of ordinary citizens into the forefront of mainstream journalism and how, in so doing, they give shape to new public conceptions of authenticity and solidarity.

\section{Journalism and Eyewitness Images Digital Media, Participation, and Conflict}

Mette Mortensen, Routledge, 2014. 194 s. ISBN 9780415828499.

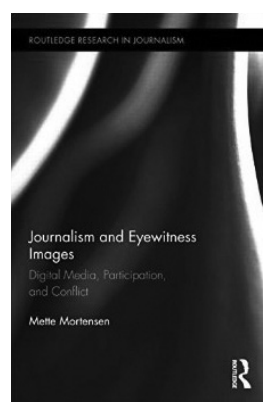

Building on the vast research conducted on war and media since the 1970s, scholars are now studying the digital transformation of the production of news. Little scholarly attention has been paid, however, to non-professional, eyewitness visuals, even though this genre holds a still greater bearing on the way conflicts are fought, communicated, and covered by the news media. This volume examines the power of new technologies for creating and disseminating images in relation to conflicts. 


\section{The African Mobile Story}

Knud Erik Skouby \& Idongesit Williams, River Publishers, 2014. 294 s. ISBN 978-87-93102-63-7, ISBN (elektronisk) 978-87-93102-64-7.

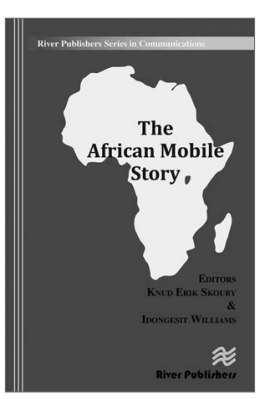

This book identifies the factors that have enabled the growth of mobile telephony in Africa. The book covers the regulatory factors, the development and usage of mobile application, mobile security and sustainable power source for mobile networks.

\section{Radio in Proportion}

The Hansen Family and strategies of relevance in the Danish Broadcasting Corporation 1925-50

Heidi Frank Svømmekjær, Roskilde: Roskilde Universitet, 2014. 226 s. Ph.d.-afhandling.

Dansk radiohistorie er på mange måder et uskrevet kapitel. Selvom der findes flere udgivelser fra Statsradiofonien selv og en dansk mediehistorie i fire bind, henligger mange centrale problemstillinger endnu i historiens mørke. Det vil nærværende afhandling søge at råde bod på med et fokus på tidlig "public service", set fra det populære spektrum og med komedieserien Familien Hansen (1929-49) som central case.

\section{Other new literature}

Fransson, J. (2014). Navigation, findability and the usage of cultural heritage on the web: an exploratory study. København: Royal School of Library and Information Science. Ph.d.-afhandling.

Hjort, M., Bondebjerg, I., \& Redvall, E. N. (2014). Danish Directors 3: Dialogues on the New Danish Documentary Cinema. Bristol: Intellect Ltd.

Kuang, X. (2014). How effective is political control over the news media?: Political censorship and news production in authoritarian China. Ph.d.-afhandling.

Michailidou, A., de Wilde, P., \& Trenz, H-J. (2014). The Internet and European Integration: Pro- and anti$E U$ debates in online news media. Barbara Budrich Publishers.

Packer, S., \& Pennington, J. (red.) (2014). A History of Evil in Popular Culture: What Hannibal Lecter, Stephen King, and Vampires Reveal about America. Santa Barbara, CA: Praeger.

\section{Articles}

Albrechtslund, A-M. B., \& Albrechtslund, A. (2014). Social Media as Leisure Culture. First Monday (Chicago), 19(4).

Baggesen, R. H. (2014). Augmenting the agora: Media and civic engagement in museums. MedieKultur, 30(56), 117-131.

Bechmann, A. (2014). Non-Informed Consent Cultures: Privacy policies and app contracts on Facebook. Journal of Media Business Studies, 11(1).

Bechmann, A., \& Lomborg, S. (2014). APIs as a method for data collection on social media. The Information Society, 30(4), 256-265.
Bondebjerg, I. (2014). Documentary and Cognitive Theory: Narrative, Emotion and Memory. Media and Communication, 2(1), 13-22.

Bro Petersen, P. (2014). Journalistic Communication. Journalism Studies, 14(6), 105-118.

Bruun, H. (2014). Conceptualizing the Audience in Political Talk Show Production. European Journal of Communication, 29(1), 3-16. [1].

Bruun, H., \& Frandsen, K. (2014). Making Sense of Television Entertainment: An Aesthetic Approach. I S. Eichner, \& E. Prommer (red.), Fernsehen: Europäische Perspektiven. (s. 39-50). UVK Verlagsgesellschaft mbH.

Dilling-Hansen, L. (2014). Recognizing the Monster Within: Lady Gaga and the Monster of the Twenty-first Century. I T. Cutler-Broyles, \& M. Teodorski (red.), Monstrosity from the Inside Out. Inter-Disciplinary Press.

Finnemann, N. O. (2014). Digitization: New trajectories of mediatization?. I K. Lundby (red.), Mediatization of Communication. (1 udg., Vol. 21, s. 297-321). Berlin: Mouton de Gruyter. (Handbooks of Communication Science, Vol. 21).

Finnemann, N. O. (2014). Research Libraries and the internet: On the transformative dynamic between institutions and digital media. Journal of Documentation, 70(2), 202-220.

Frandsen, K. (2014). Mediatization of sport. I K. Lundby (red.), The Handbook of Mediatization of Communication. (s. 525-543). Kapitel 23.Berlin: Mouton de Gruyter.

Frølunde, L., \& Bjerregaard, M. (2014). The articulation of voices in two film projects about violence: The Act of Killing and Gzim Rewind. MedieKultur, 30(56), 132-150. 
Givskov, C., \& Trenz, H-J. (2014). Civic engagement through mainstream online newspapers: Possibilities and shortcomings. MedieKultur, 30(56), 44-60.

Gregersen, A. L. (2014). Generic Structures, Generic Experiences: A Cognitive Experientialist Approach to Video Game Analysis. Philosophy \& Technology, 1-17.

Hald, G. M., Seaman, C., \& Linz, D. (2014). Sexuality and Pornography. I D. Tolman, L. Diamond, J. Bauermeister, W. George, J. Pfaus, \& M. Ward (red.), APA Handbook of Sexuality and Psychology: Vol. 2. Contextual Approaches.. (s. 3-35). Kapitel 1.Washington, DC: American Psychological Association.

Hassall Thomsen, L. (2014). Ethnographic Fieldwork: Studying Journalists at Work. SAGE Research Methods Cases.

Hjarvard, S. (2014). From Mediation to Mediatization: The Institutionalization of New Media. I A. Hepp, \& F. Krotz (red.), Mediatized Worlds: Culture and Society in a Media Age. Kapitel 8.London: Palgrave Macmillan.

Hjarvard, S. (2014). Mediatization and cultural and social change: an institutional perspective. I K. Lundby (red.), Mediatization of communication. (Vol. 21, s. 199-226). Kapitel 9.Berlin / Boston: Walter de Gruyter. (Handbooks of Communication Science, Vol. 21).

Hjarvard, S., \& Kristensen, N. N. (2014). When media of a small nation argue for war. Media, War \& Conflict, 7(1), 51-69.

Iversen, S. M. (2014). Paradox and pleasure: Play with everyday life in a ludic simulation. MedieKultur, 30(56), 100-116.

Jensen, I., \& Andreasen, L. B. (2014). Methods for researching intercultural communication in globalized complex societies. I S. Poutiainen (red.), Theoretical Turbulence in Intercultural Communication Studies. (s. 45-62). Newcastle upon Tyne, UK: Cambridge Scholars Press.

Jensen, J. L. (2014). Online deliberation and beyond?: A time-based and comparative study of Danish political debates online. MedieKultur, 30(56), 23-43.

Kobbernagel, C. (2014). Factors enhancing learning possibilities in digital workshops. MedieKultur, 30(56), 170-190.

Ladegaard, J. (2014). Laughing Matters: Four Marxist Takes on Film Comedy. I E. Mazierska, \& L. Kristensen (red.), Marx at the Movies: Revisiting History, Theory and Practice. (s. 102-122). Palgrave Macmillan

Meyer, G., \& Lund, A. B. (2014). Almost Lost in Translation: Tale of an Untold Tradition of Journalism. I M. Broersma, \& C. Peters (red.), Retelling Journalism:
Conveying Stories in a Digital Age. (s. 27-45). Kapitel 2.Leuven: Peeters. (Groningen Studies in Cultural Change, Vol. XLIX).

Ngomba, T. J. (2014). A Unique Period?: An Analysis of the Coverage of Africa during the 2010 FIFA World Cup in Selected Western Media. I T. Chari, \& N. A. Mhiripiri (red.), African Football, Identity Politics and Global Media Narratives: The Legacy of the FIFA 2010 World Cup. (s. 231-261). Kapitel 12.London: Palgrave Macmillan.

Nielsen, R. K. (2014). Political communication research: New media, new challenges, and new opportunities. MedieKultur, 30(56), 5-22.

Nielsen, R. K., \& Schrøder, K. C. (2014). The relative importance of social media for accessing, finding, and engaging with news: An eight-country cross-media comparison. Digital Journalism, 1-18.

Pedersen, P. O., \& Stephensen, J. L. (2014). Paranoid, moi?: Surveillance and the Popular Cultural Documentary . Panoptikum, 12(19), 152-172.

Raskin, R. (2014). A shot-by-shot breakdown of "Body Memory/ Keha Mälu”. Short Film Studies, 4(2), 130137.

Raun, T. (2014). Video blogging as a vehicle of transformation: Exploring the intersection between trans identity and information technology. International Journal of Cultural Studies, 1367-8779.

Roslyng-Jensen, P. (2014). War observed at a Distance: Media Coverage and Attitudes to War in Denmark, 1939-1940. I G. Lind (red.), Civilians at War: From the Fifteenth Century to the Present. (s. 145-183). Copenhagen: Museum Tusculanum.

Schrøder, K. C. (2014). News consumption in a multiplatform age: The role of television news. I S. Eichner, \& E. Prommer (red.), Fernsehen: Europäische Perspektiven. (s. 173-196). Konstanz og München: UVK Verlagsgesellschaft mbH. (Alltag, Medien und Kultur, Vol. 16).

Schrøder, K. C. (2014). News media old and new: Fluctuating audiences, news repertoires, and locations of consumption. Journalism Studies, 1.

Soon, W. (2014). What is Media Archaeology?. International Journal of Performance Arts and Digital Media, 10(1).

Stage, C. (2014). The Entrepreneurial Illness Blogger: On Entrepreneurial Illness Communication and the Transformative Potential of Public Affect. I D. R. Christensen, B. T. Knudsen, \& P. Blenker (red.), Enterprising Initiatives in the Experience Economy. Routledge. 
Søndergaard, H., \& Helles, R. (2014). Media Policy and New Regulatory Systems in Denmark. I . E. Psychogiopoulou (red.), Media Policies Revisited. (s. 41-54). London: Palgrave Macmillan.

Uldam, J. (2014). Corporate Management of Visibility and the Fantasy of the Post-political: Social Media and Surveillance. New Media and Society.

Valtysson, B. (2014). Democracy in Disguise: The Use of Social Media in Reviewing the Icelandic Constitution. Media, Culture and Society, 36(1), 52-68.
Westlund, O. (2014). The production and consumption of mobile news. I G. Goggin, \& L. Hjorth (red.), The Routledge companion to mobile media. (s. 135-145). New York: Routledge.

Westlund, O., \& Bjur, J. (2014). Media life of the young. Young, 22(1), 21-41.

Wien, C. (2014). Commentators on daily news or comunicators of scholary achievements?: The role of researchers in Danish news media. Journalism : theory, practice \& criticism, 1464-8849. 


\section{Finland \\ Documentalist Eija Poteri}

\section{Collective Intelligence in Open Journalism \\ Power, Knowledge and Value}

Tanja Aitamurto, Tampere, 2014. 326 p. Doctoral dissertation in the University of Tampere.

The study inquires about the change of societal power structures and power production practices in media by examining journalism as an empirical context. The rise of participatory culture alters the traditional audienceproducer dichotomy and blurs the boundaries of those roles. The dissertation is shaped by the multidisciplinary approach: communication and journalism studies, engineering sciences, computer science, information systems, organization research and political science.

\section{Law and Community in the New Media ILandscape}

Critical Perspectives on Audiovisual Sport Coverage in the European Union

Anette Alén-Savikko, Helsinki: University of Helsinki, 2014. 407 p. ISBN 978-952-10-9768-3. Doctoral dissertation.

This doctoral dissertation focuses on audiovisual sport coverage in the new media landscape and provides a critical, EU level analysis. Multiple layers of exclusive aspirations exist alongside a striving for maximum exposure and public appeal: sport broadcasting rights in particular have been questioned as their costs have risen and sport content has been moved behind conditional access. These tendencies have then provoked fundamental rights discussions on access by the public to information, pluralism of the media, and freedom of expression.

\section{Finnish Consumption}

AnEmergingConsumerSociety Between EastandWest

Visa Heinonen, Matti Peltonen (eds.) Helsinki: SKS, 2013. 262 p. ISBN 978-952-222-522-1.

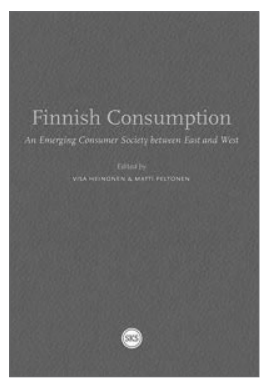

The formation of the Finnish type of consumer society between the East and the West in the 1950s and 1960s, as well as, the Finnish consumer mentality and ethos are main topics in the anthology. Besides editors, the article authors are Minna Autio, Minna Lammi, Päivi Timonen, Janne Poikolainen, Jukka Kortti, Riitta Matilainen, Hanna Kuusi and Kaarina Kilpiö.

The authors focus, for example, on television, popular music, alcohol and trips to abroad.

\section{Memoria Virtualis \\ Death and Mourning Rituals in Online Environments}

Anna Haverinen, Turku: University of Turku, 2014. 242 p. ISBN 978-951-29-5772-9. Doctoral dissertation.

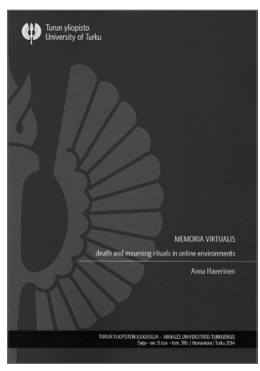

The main objective of this work has been to understand the ritual aspect of how private people use the Internet to mourn and honor their intimates in various online environments. The research material was compiled in 2007-2013 through ethnographic and autoethnographic observations in social media applications, online memorial websites, one shared virtual environment (Second Life) and one massive multi-player online role-playing game (World of Warcraft). The research material consists also of three online surveys with 153 respondents (mainly from Finland, the United States and the United Kingdom). In addition, the researcher conducted 38 longer online interviews (i.e. via email, an avatar). The theoretical framework is derived from ritual theory, hermeneutic-phenomenological anthropology and discourse analysis.

\section{Disconnect Me}

User Engagement and Facebook

Tero Karppi, Turku: University of Turku, 2014. 178

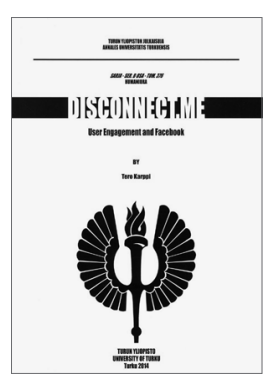
p. ISBN 978-951-29-5666-1. Doctoral dissertation.

In the beginning of its 10 th year of existence Facebook has engaged and connected 1.2 billion monthly active users. This article-based dissertation approaches this engagement from the opposite direction: disconnection. The research articles focus on social media specific phenomena including leaving Facebook, tactical media works, such as Web 2.0 SuicideMachine, memorializing dead Facebook users and Facebook trolling. The media theoretical framework for this study is built around affect theory, software studies, biopolitics, as well as different critical studies of new media. 


\section{Joukkoviestimet 2013 - Finnish Mass Media 2013}

Tuomo Sauri (ed.) Helsinki: Statistics Finland, 2014. 157 p. ISBN 978-952-244-500-1.

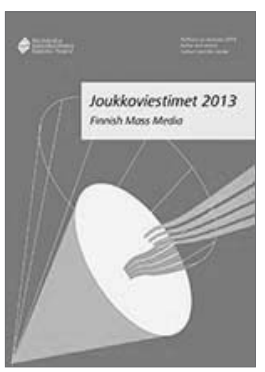

The Finnish Mass Media is a versatile review based on articles and statistical data on the state of Finland's mass media. The publication examines the following mass media sectors: the economy and consumption of mass media, newspapers, periodicals, radio, television, and media services on the web. The publication also has a section containing international comparison data. Concise summary articles are available on each mass media sector in connection with the statistical reviews. Statistical tables are also in English.

\section{Confessions in Social Media}

Performative, Constrained, Authentic and Participatory Self-representations in Vlogs

Karoliina Talvitie-Lamberg, Helsinki: University of Helsinki, 2014. 217 p. ISBN 978-952-10-9107-0. Doctoral dissertation.

In this dissertation, the author studies confessional mecentered communications of vlogs in the context of DIY (Do It Yourself) cultures, in YouTube and in webcam communities. Confession refers to a communicative strategy that aims to reveal intimate matters of an individual and, at the same time, serves as a way to socialize with others. The key research question is: How and why does confession operate in communication and interaction in social media environments?

\section{Blogization of Journalism}

\section{How Blogs Politicize Media and Social Space in} Russia

Dmitry Yagodin, Tampere, University of Tampere, 2014. 315 p. ISBN 978-951-44-9450-5. Doctoral dissertation.

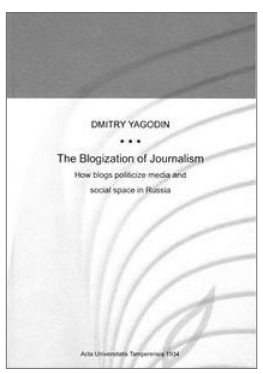

Blogization is the term that describes the current state of Russian journalism and considers its broader implications for political and social life. This thesis argues that the stability of traditional mass media in Russia is secured by the strategic control and support of the state; that online media are less susceptible to the influence of the state.

The project's core empirical data includes eight examples of mass media and eight Russian bloggers, who are all important actors in the blogization process. The sub-sample of bloggers includes individuals with large readerships who come from various backgrounds and professional orientations: pro-Kremlin and oppositional bloggers, trained journalists and blogging celebrities. It also covers different genres ranging from investigative and opinionated reporting, to facts, aggregate stories, and daily life reflections. The initial overview of relations between journalism and blogging is based on official reports and media statistics.

\section{Other new literature}

\section{Articles}

Ahva, L., Heikkilä, H., Siljamäki, J., \& Valtonen, S. (2014). A bridge over troubled water?: celebrities in journalism connecting implicit and institutional politics. Journalism: theory, practice \& criticism, 15(2), 186-201.

Ahva, L., \& Pantti, M. (2014). Proximity as a journalistic keyword in the digital era: a study on the "closeness" of amateur news images. Digital Journalism, 2(3), 322-333.

Ala-Kortesmaa, S., \& Isotalus, P. (2014). Relational tensions and optimal listening in the communication relationships of American and Finnish legal professionals. Journal of Intercultural Communication Research, 43(3), 173-193.

Harisalo, R., Rajaniemi, J., Stenvall, J., \& Vallin, T. (2014). Emergent positive culture in a media organisation: Satakunnan Kansa a newspaper case study. Journal of Media Business Studies, 11(3).
Herzog, C., \& Karppinen, K. (2014). Policy streams and public service media funding reforms in Germany and Finland. European Journal of Communication, 29(4), 416-432.

Isotalus, P., \& Almonkari, M. (2014). Mediatization and political leadership. Journalism Studies, 15(3), 289-303.

Kantola, A. (2014). Branded revolutionaries: circulated gurus as management tools in soft capitalism. European Journal of Cultural Studies, 17(3), 258-274.

Kantola, A. (2014). Emotional styles of power: corporate leaders in Finnish business media. Media, Culture and Society, 36(5), 578-594.

Kantola, A. (2014). Unholy alliances: competitiveness as domestic power strategy. In P. Alasuutari, \& A. Qadir (Eds.), National policy-making: domestication of global trends. (pp. 44-60). Abingdon, Oxon: Routledge. 
Mannevuo, M. (2014). Reading the faces of hunger: disturbing images of child malnutrition in the World Press Photo competition. European Journal of Cultural Studies, 17(2), 134-148 .

Myllylahti, M. (2014). Newspaper paywalls: the hype and the reality: a study of how paid news content impacts on media corporation revenues. Digital Journalism, 2(2), 179-194.

Mäkinen, L. A., \& Koskela, H. (2014). Surveillance as a reality game. In A. Jansson, \& M. Christensen (Eds.), Media, surveillance and identity: social perspectives. (pp. 183-200). New York: Peter Lang. (Digital formations, Vol. 84).

Nieminen, H. (2014). A short history of the epistemic commons: critical intellectuals, Europe and the small nations. Javnost - the Public, 21(3), 55-76.

Nikunen, K. (2014). Losing my profession: age, experience and expertise in the changing newsrooms . Journalism: theory, practice \& criticism, 15(7), 868-888.
Saarenmaa, L., \& Ruoho, I. (2014). Women's magazines in the Nordic style: politics, politicians and the welfare state. European Journal of Communication, 29(3), 289-303.

Valaskivi, K., \& Sumiala, J. (2014). Circulating social imaginaries: theoretical and methodological reflections. European Journal of Cultural Studies, 17(3), 229-243 .

Vähämaa, M., \& West, M. D. (2014). The dilemma of group membership in the Internet age: public knowledge as preferred misinformation. Javnost - the Public, 21(1), 5-18.

Wang, L., Alasuutari, P., \& Aro, J. (2014). Aesthetic and family frames in the online sharing of children's birthday photos. Visual Communication, 13(2), 191-209. 


\section{Norway \\ Documentalist: Ragnhild Mølster}

\section{Representational Machines}

Photography and the Production of Space

Nina Lager Vestberg, Anna Dahlgren \& Dag Petersson. Aarhus: Aarhus Universitetsforlag, 2013. 269 s. ISBN 9788771241655.

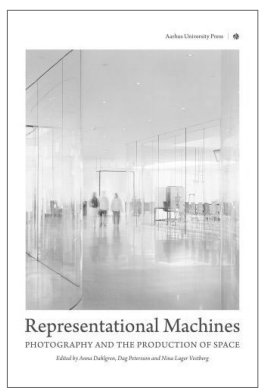

Photography not only represents space. Space is produced photographically. Since its inception in the 19th century, photography has brought to light a vast array of represented subjects. Always situated in some spatial order, photographic representations have been operatively underpinned by social, technical, and institutional mechanisms. Geographically, bodily, and geometrically, the camera has positioned its subjects in social structures and hierarchies, in recognizable localities, and in iconic depth constructions which, although they show remarkable variation, nevertheless belong specifically to the enterprises of the medium. This is the subject of Representational Machines: How photography enlists the workings of institutional technologies in search of establishing new iconic and social spaces. Together, the contributions to this edited volume span historical epochs, social environments, technological possibilities, and genre distinctions. Presenting several distinct ways of producing space photographically, this book opens a new field of inquiry for photography research.

\section{Mediatization of Communication}

Knut Lundby, (red.). Berlin: Mouton de Gruyter, 2014. 738 s. ISBN 978-3-11-027193-5.

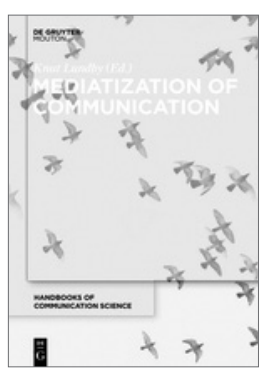

This handbook on Mediatization of Communication uncovers the interrelation between media changes and changes in culture and society. This is essential to understand contemporary trends and transformations. "Mediatization" characterizes changes in practices, cultures and institutions in media-saturated societies, thus denoting transformations of these societies themselves. This volume offers 31 contributions by leading media and communication scholars from the humanities and social sciences, with different approaches to mediatization of communication. The chapters span from how mediatization meets climate change and contribute to globalization to questions on life and death in mediatized settings. The book deals with mass media as well as communication with networked, digital media. The topic of this volume makes a valuable contribution to the understanding of contemporary processes of social, cultural and political changes.

\section{Cinema and Agamben}

Henrik Gustafsson \& Asbjørn Grønstad, (eds) London: Bloomsbury Academic, 2014. 248 s. ISBN 978-162356-436-0.

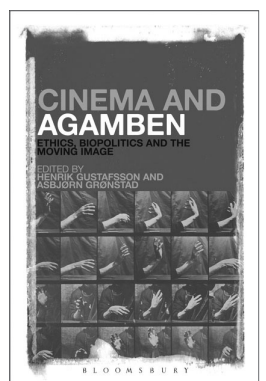

Cinema and Agamben brings together a group of established scholars of film and visual culture to explore the nexus between the moving image and the influential work of Italian philosopher Giorgio Agamben. Including two original texts by Agamben himself, published here for the first time in English translation, these essays facilitate a unique multidisciplinary conversation that fundamentally rethinks the theory and praxis of cinema. In their resourceful analyses of the work of artists such as David Claerbout, Jean-Luc Godard, Philippe Grandrieux, Michael Haneke, Jean Rouch, and others, the authors put to use a range of key concepts from Agamben's rich body of work, like biopolitics, decreation, gesture, potentiality and profanation. Sustaining the eminently interdisciplinary scope of Agamben's writing, the essays all bespeak the importance of Agamben's thought for forging new beginnings in film theory and for remedying the elegiac proclamations of the death of cinema so characteristic of the current moment. - See more at: http://www.bloomsbury.com/us/cinema-andagamben-9781623561253/\#sthash.E8P4iXVI.dpuf

\section{Delineating Boundaries Between ' $U$ s' and 'Them'}

A Reception Study of the Representation of Muslim Characters in the Television Serial 24

Rolf E. S. Halse, Bergen: Universitetet i Bergen, Institutt for Informasjons- og medievitenskap, 2014. 236 s. Ph.d.-avhandling.

This thesis presents an examination of the US television serial 24 's representation of Muslim characters, and it explores to what extent the perception of these characters can be determined by the cultural and ethnic belonging of the audience. The present thesis shows how 24 participated in forming an arena in which representations, mental images, social relations, and boundaries between ingroup members and outgroup members are constructed and negotiated. The main reason for choosing to study 24 exclusively is that after $9 / 11$ the serial played a central role in the public debate about whether Muslims are being stereotyped in US television enter- 
tainment. Hence, the thesis examines whether the critics of 24 have a valid point with regards to the show's portrayal of negative stereotypes. It also assesses to what extent the serial's effort to introduce Muslim counterstereotypes proved to be an adequate response to the criticism. A qualitative research approach is used for examining 24 by combining textual and audience reception analysis. Close readings of elected episodes of the TV serial is carried out, and the crux of the analysis centres on whether, and if so in what respects the representation of the characters are stereotypical/counter-stereotypical. Moreover, it is examined how different interpretive communities of young adults, mainly from Norway, but also from the United States, read and perceive the portrayal of Muslim characters in the same television texts.

\section{Personal Media and Everyday Life}

\section{A Networked Lifeworld}

Terje Rasmussen, Houndmills, Basingstoke, Hampshire: Palgrave Macmillan, 2014. 140 s. ISBN 978-1137-44645-9.

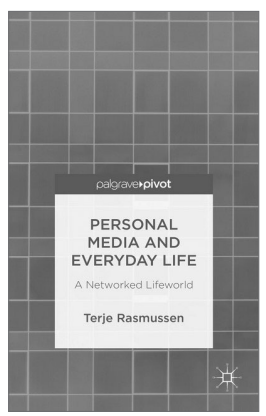

This book argues that the plethora of new genres, apps and services in digital personal media must be understood historically and sociologically, and insists that sociology, media and communication theory can provide insight beyond surveys on media use and effects. It introduces key terms like 'personal media', 'personalisation' and the 'lifeworld' in order to embed current media use in a proper historical context and theoretical framework. Theorists like McLuhan, Goffman, Habermas, Luhmann, Bauman, de Certeau and Foucault are discussed to indicate the formative power of personal media in daily life. This book argues that mass communication models will not do in examining the use of personal media. Key communication theories are discussed along with the concepts of skills, social capital and social network.

\section{Seeing Ourselves through Technology}

How We Use Selfies, Bogs and Wearable Devices to See and Shape Ourselves

Jill Walker Rettberg, Palgrave Macmillan, 2014. 120 s. ISBN 9781137476647, ISBN (elektronisk) 978113 7476661, 9781137476654.

Selfies, blogs and lifelogging devices have become important ways in which we understand ourselves. Jill Walker Rettberg analyses these and related genres as three intertwined modes of self-representation: visual, written and quantitative. Rettberg explores topics like the meaning of Instagram filters, smartphone apps that write your diary for you, and the ways in which governments and commercial entities create their own representations of us from the digital traces we leave behind as we go through our lives.

\section{The Media Welfare State Nordic Media in the Digital Era}

Trine Syvertsen, Gunn Sara Enli, Hallvard Moe \& Ole Johan Mjøs, University of Michigan Press, 2014.

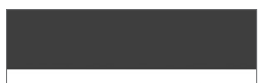

The Media Welfare State: Nordic Media in the Digital Era
THE MEDIA WELFARE STATE

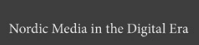

Nordic Media in the Digital Era

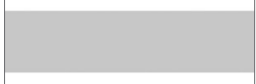

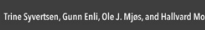
comprehensively addresses the central dynamics of the digitalization of the media industry in the Nordic countries - Sweden, Norway, Denmark, Finland, and Iceland - and the ways media organizations there are transforming to address the new digital environment. Taking a comparative approach, the authors provide an overview of media institutions, content, use, and policy throughout the region, focusing on the impact of information and communication technology/ internet and digitalization on the Nordic media sector. Illustrating the shifting media landscape the authors draw on a wide range of cases, including developments in the press, television, the public service media institutions, and telecommunication.

\section{Other new literature}

\section{Articles}

Bastiansen, H. G. (2014). Norwegian media and the cold war. Nordicom Review, 35, 155-169.

Beyer, A., \& Figenschou, T. U. (2014). Human-Interest Fatigue: Audience Evaluations of a Massive Emotional Story. International Journal of Communication, 8.

Beyer, A., Knutsen, C. H., \& Rasch, B. E. (2014). Election Campaigns, Issue Focus and Voting Intentions:
Survey Experiments of Norwegian Voters. Scandinavian Political Studies. Colbjørnsen, T. (2014). What is the VAT?. The International Journal of Cultural Policy.

Colbjørnsen, T. (2014). Digital divergence: analysing strategy, interpretation and controversy in the case of the introduction of an ebook reader technology. Information, Communication and Society, 18(1), 32-47.

Colbjørnsen, T. (2014). The construction of a bestseller: theoretical and empirical approaches to the case of the 
Fifty Shades trilogy as an eBook bestseller. Media Culture and Society, 38, 1-18.

Dahlén, P. (2014). The olympic creation as a sacred story: history and myth in Jens Lind's documentary The Sunshine Olympics 1912. International Journal of the History of Sport, 31, 557-569.

Donders, K., \& Moe, H. (2014). European State-Aid Control and PSB. I K. Donders, C. Pauwels, \& J. Loisen (red.), The Palgrave Handbook of European Media Policy. (s. 426-441). Basingstoke: Palgrave Macmillan.

Eide, M. (2014). Accounting for Journalism. Journalism Studies, 679-688.

Eide, E., Krøvel, R., \& Knudsen, A. M. (2014). Transnational orientations in a global media landscape. Conflict \& Communication Online, 13.

Figenschou, T. U., \& Beyer, A. (2014). The Limits of the Debate: How the Oslo Terror Shook the Norwegian Immigration Debate. The International Journal of Press/ Politics.

Grønstad, A., \& Gustafsson, H. (2014). Giorgio Agamben and the Shape of Cinema to Come. I H. Gustafsson, \& A. Grønstad (red.), Cinema and Agamben. (s. 1-17). Continuum International Publishing Group Ltd.

Hanssen, E. F. (2013). To look, to respond: vantage points and mixed media in Brian De Palma's 1960s and 2000s. La Furia Umana, 108-113.

Hanssen, E. F. (2014). Head/Face/Cabbage. La Furia Umana.

Hausken, L. (2014). Forensic fiction and the normalization of surveillance. Nordicom Review, 35, 3-16.

Hausken, L. (2014). The Visual Culture of Brain Imaging. Leonardo: Journal of the International Society for the Arts, Sciences and Technology. 10.1162/LEON_a_00899

Hornmoen, H., \& Steensen, S. (2014). Dialogue as a Journalistic Ideal. Journalism Studies, 543-554.

Høier, S. (2014). Surrounded by ear candy?: The Use of Surround Sound in Oscar-nominated Movies 2000-2012. Nordicom Review, 35, 251-262.
Ihlebæk, K. A., \& Krumsvik, A. H. (2014). Editorial power and public participation in online newspapers. Journalism - Theory, Practice \&amp; Criticism.

Ihlen, Ø., \& Pallas, J. (2014). Mediatization of corporations. I K. Lundby (red.), Mediatization of communication. (s. 423-441). Berlin: Mouton de Gruyter.

Krumsvik, A. H. (2014). Newspaper Ownership And The Prioritization Of Digital Competences. Digital Journalism.

Krumsvik, A. H. (2014). Stability in Times of Change: Trends in Newspaper Executives' Attitudes towards Digital Media. Nordicom Review, 35(1), 97-108.

Krumsvik, A., \& Ots, M. (2014). Is there such a thing as a Nordic approach to media business research?. Journal of Media Business Studies, 11(1).

Liestøl, G., \& Morrison, A. (2014). The power of place and perspective: sensory media and situated simulations in urban design. I M. Sheller, \& A. de Souza e Silva (red.), Mobility and Locative Media. (s. 207-223). Routledge/ Taylor and Francis Group.

Livingstone, S., Kirwil, L., Ponte, C., \& Staksrud, E. (2014). In their own words : What bothers children online?. European Journal of Communication.

Lundby, K. (2014). Mediatized Stories in Mediatized Worlds. I A. Hepp, \& F. Krotz (red.), Mediatized Worlds. (s. 19-37). Houndmills, Basingstoke, Hampshire: Palgrave Macmillan.

Moe, H., \& van den Bulck, H. (2014). Comparing "Public Value" as a Media Policy Term in Europe. I G. F. Lowe, \& F. Martin (red.), The Value of Public Service Media. (s. 57-76). Göteborg: NORDICOM.

O’Moore, M., Donna, C., Valimaki, M., Almeida, A., Berne, S., Fandrem, H., Stald, G. (2013). Guidelines to prevent cyberbullying: a cross-national review. I Peter K. Smith, Georges Steffgen (red.), Cyberbullying through the new media: Findings from an international network. (s. 136-161). Psychology Press. 


\section{Sweden \\ Documentalist: Karin Poulsen}

\section{Cyberbullying in Childhood and Adolescence}

Assessment, Coping, and the Role of Appearance

Sofia Berne, University of Gothenburg, Department of Psychology, 2014, 242 p., (Doctoral Theses from University of Gothenburg / Doktorsavhandlingar från Göteborgs universitet) ISBN 978-91-628-9060-5 (print) ISBN 978-91-62890-60-2 (pdf). Doctoral Dissertation.

Cyberbullying is a relatively new form of bullying that is conducted through modern information and communication technology. This thesis examines different aspects of cyberbullying, and is comprised of three parts.

The first part aims to extend our understanding of an almost unexplored area - the relationship between cyberbullying and appearance - using self-report questionnaires and focus

The second part of this thesis investigated the coping strategies that 697 pupils in the 4th and 6th grades suggested they would use if they were cyberbullied, with a special focus on whether there were differences in these strategies related to age and gender. The most commonly suggested coping strategy was telling someone (70.5\%), especially parents $(39.5 \%)$ and teachers $(20.2 \%)$. Surprisingly, few pupils reported that they would tell a friend (2.6\%). Differences in suggested coping strategies were found related to age and gender.

The third and final part of this thesis, Study IV, aimed to offer a representative overview of instruments designed to assess the prevalence of cyberbullying.

\section{Study of Video Practices Video at Work}

Mathias Broth, Eric Laurier \& Lorenza Mondada, New York, Routledge, 2014, 294 p. (Routledge research in media and cultural studies) ISBN 978-0-415-72839-3-

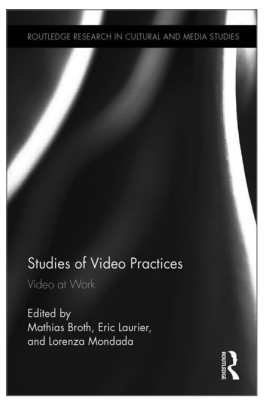

The last two decades have seen a rapid increase in the production and consumption of video by both professionals and amateurs. The near ubiquity of devices with video cameras and the rise of sites like YouTube have lead to the growth and transformation of the practices of producing, circulating, and viewing video, whether it be in households, workplaces, or research laboratories.

This volume builds a foundation for studies of activities based in and around video production and consumption. It contributes to the interdisciplinary field of visual methodology, investigating how video functions as a resource for a variety of actors and professions.

\section{Cosmopolitanism in a Mediatized World}

The Social Stratification of Global Orientations

Johan Lindell, Karlstad University, 2014, 242 p., (Karlstad University Studies; 23) ISBN 978-91-7063-554-0. Doctoral Dissertation

The contemporary media landscape invites us to experience a belonging to various distant places, mourn the victims of faraway disasters, expose ourselves to foreign cultures and engage in political issues in places far from our local context of living. In other words, we are invited to become citizens of the world - cosmopolitans. But are we? And if so, how is such cosmopolitanism expressed in a given society, under what social conditions, and in relation to what media practices?

Contemporary social theory depicts a global or cosmopolitan mode of orienting in the world as paradigmatic of social life in global modernity. To date, little is known about the structural realities of such orientations. Against this backdrop, the aim of the present study is to understand the potentially "cosmopolitan" character of peoples' outlooks and practices, and the societal conditions in which they can be identified. On the one hand, the aim of the study is to contribute to the largely theoretical accounts of the "cosmopolitan" character of social life in present times, andon the other, to understand the specific role of various media practices in the process generally described as "cosmopolitanization".

\section{Researching the Use of Internet Assessment, Coping, and the Role of Appearance}

Håkan Selg, Uppsala University, The Faculty of Science and Technology, 2014, 254 p., (Uppsala Dissertations from the Faculty of Science and Technology; 9) ISSN 1104 2516, ISBN 978-91-554-9061-4. Doctoral Dissertation.

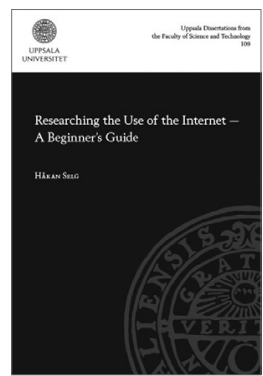

Information and communication technologies (ICT) have experienced a technological convergence. Laptops, tablets and smartphones integrate previously distinct artefacts and communication protocols within information systems, personal computers and telephony. Yet the previous division is still reflected in different research traditions as

regards the uses of ICTs.

Internet studies is a multidisciplinary field of science. However, diversity with regard to concepts, terminology, assumptions about the users etc., is a characteristic feature. Basic assumptions and perspectives are lacking or not explicitly stated, leading to claims that it is 'under- 
theorised'. These conditions contribute to an amorphous picture of Internet studies as field of research.

Using a hermeneutic perspective based on the interpretation of written records and with understanding as the aim of knowledge, the author proposes a methodological framework to structure and describe Internet studies with focus on theories and guiding assumptions.

The approach builds on Lakatos' concept of research programmes, characterised by a core of basic assumptions that remain stable over time with supporting theories that may be modified or replaced depending on changes in research focus. An analytical tool, 'a map', to provide an overview by which Internet studies may be classified, is also proposed.
The applicability of the methodological framework and the map are tested against empirical studies on Internet use carried out by the author between 2002 and 2011 .

The author discusses an analytically guided methodology that draws on (1) the kind of user action referred to in the research question and (2) the knowledge aim of study, as an alternative to research methodologies guided by epistemological perspectives.

While understanding that the findings are partially subjective, the author argues that the proposed methods 'per se' are generalisable within multidisciplinary fields of research and that their application would greatly improve the academic standing of Internet studies.

\section{Other new literature}

Andersson, Ulrika; Wiik, Jenny. New Demands on Editorial Leadership: Perceived Changes in Swedish Newspaper Management. I: OBS - Observatorio. 2014; Vol.8, No.2, ISSN1646-5954.

Bergström, Annika; Höglund, Lars. A national survey of early adopters of e-book reading in Sweden. I: Information Research. 2014; Vol.19, No.2, ISSN1368-1613.

Brusk, Jenny. Steps towards creating socially competent game characters. Göteborg: Göteborgs universitet, Institutionen för filosofi, lingvistik och vetenskapsteori, 2014, (Doctoral Theses from University of Gothenburg; 44), 225 s.,ISBN 978-91-628-8890-9.

Jansson, André (red.); Christensen, Miyase (red). Media, surveillance and identity: social perspectives. New York: Peter Lagn, 2014. 262 s. ISBN 9781433118791

Manduchi, Agostino; Naldi, Luica. Clusters and conglomerates in the media industry. Edward Elgar Publishing, 2014. 15 s. ISBN 9781849809269.

\section{Articles}

Broth, Mathias. Pans, tilts and zooms: conventional camera gestures in tv-production. I: Studies of video practices : video at work. red. Broth, M.; Laurier, E.; Mondala, L. New York: Routledge, 2014. s. 63-96. ISBN 978-0-415-72839-3

Cyrén Wormbs, Nina. Negotiating the Radio Spectrum: The Incessant Labor of Maintaining Space for European Broadcasting. I: Cosmopolitan Commons : Sharing Resources and Risks across Borders. MIT Press, 2014. s. 97-122. ISBN 978-0-262-51841-3

Djerf-Pierre, Monika; Ekström, Mats; Håkansson, Nicklas; Johansson, Bengt. The Mediatization of Political Accountability: Politics, the news media logic and indus- trial crises in the 1980s and 2000s. I: Journalism Studies. 2014; Vol.15, No.3, s. 321-338, ISSN1461-670X.

Ekström, Mats; Moberg, Ulla. 'Welcome to participate': Host activities and caller's position in Swedish election campaign phone-ins in the 1970s and 2000s. I: Journalism : Theory, Practice \& Criticism. 2014. ISSN1464-8849.

Ekström, Mats; Olsson, Tobias; Shehata, Adam. Spaces for public orientation?: longitudinal effects of internet use in adolesence. I: The networked young citizen: Social media, political participation and civic engagement. red. Loader, Brian D.; Vromer, Ariadne; Xenos, Michael A. Routledge, 2014. s. 39-59. ISBN 978-1315-77859-4, ISBN (elektronisk) 978-1-138-01999-7.

Forsman, Michael; Hernwall, Patrik; Siibak, Andra. Employing Creative Research Methods with Tweens in Estonia and Sweden: Reflections on a Case Study of Identity Construction on Social Networking Sites. I: Methods for Analyzing Social Media. Routledge, 2014. s. 250-261. ISBN 978041581832

Fredriksson, Magnus. Crisis Communication as Institutional Maintenance. I: Public Relations Inquiry. 2014; Vol.3, ISSN2046-147X.

Fredriksson, Magnus; Johansson, Bengt. The Dynamics of Professional Identity: Why journalists view journalists working with $P R$ as a threat to journalism. I: Journalism Practice. 2014; Vol.8, No.5, s. 585-595, ISSN1751-2786.

Fredriksson, Magnus; Pallas, Josef; Wehmeier, Stefan. Institutional perspectives on public relations. I: Strategic Communication. red. Heath, R.L.; Gregory, A. Thousand Oaks: SAGE, 2014.

Ghersetti, Marina. Still the same?: Comparing news content in online and print media. I: Journalism Practice. 2014; Vol. 8 , No.4, s. 373-389, ISSN1751-2786. 
Ghersetti, Marina; Odén, Tomas. Communicating crisis through mass media. I: Current issues in crisis communication and alerting. red. Klafft, Michael. Berlin: Fraunhofer Verlag, 2014. s. 24-42. ISBN 978-3-83960737-4

Hedman, Ulrika. J-Tweeters: Pointing towards a new set of professional practices and norms in journalism. I: Digital Journalism. 2014. s. 1-19, ISSN2167-0811.

Hänska-Ahy, Maximillian. Networked communication and the Arab Spring: Linking broadcast and social media. I: New Media and Society. 2014. ISSN1461-4448.

Ihlen, Øyvind; Pallas, Josef. Meditizaiton of corporations. I: Mediatization of communication. red. Lundby, Knut. Berlin: Mouton de Gruyter, 2014. s. 423-441. ISBN 978-3-11-027193-5

Larsson, Anders Olof; Moe, Hallvard. Twitter in politics and elections: insights from Scandinavia. I: Twitter and society. red. Weller, Katrin. New York: Peter Lang, 2014. s. 319-330. ISBN 978-1-4331-2170-8

Larsson, Stefan. Conceptions of copyright in a digital context: A comparison between French and American file-sharers. I: Lexis - E-Journal in English Lexicology. 2014; No.8, s. 89-102, ISSN1951-6215.

Olausson, Ulrika; Berglez, Peter. Media and climate change: Four long-standing research hallenges revisited. I: Environmental Communication: A Journal of Nature and Culture. 2014; Vol.8, No.2, s. 249-265, ISSN1752-4032.

Ots, Mart. Sweden: State Support to Newspapers in Transition. I: State Aid for Newspapers Theories, Cases, Actions. red. Murschetz, Paul. Springer Berlin / Heidelberg, 2014. s. 307-322. ISBN 978-3-642-35690-2

Pallas, Josef; Fredriksson, Magnus. Media enactments: where to look for inspiration in mediatization studies. I: Organizations and the media: organizing in a mediatized world. New York: Routledge, 2014. s. 234-248. ISBN 978-3-11-027222-2.

Petrelius Karlberg, Pernilla; Windell, Karolina; Grafström, Maria. The creation of a crisis of confidence: A study of the mediatization of the Red Cross. I: Trust and organizations : Confidence across borders. Palgrave Macmillan, 2014. ISBN 978-1-137-37074-7

Picard, Robert G.; Kivikuru, Ullamaija. Katsaus maailman mediaan [A review over the media of the world]. I: Maailman media. red. Kivikuru, Ullamaija; Pietiläinen, Jukka. Helsinki: University of Helsinki, 2014. s. 20-45. ISBN 978-952-10-9119-3, ISBN (elektronisk) 978-952-10-9120-9
Pollack, Ester; Allern, Sigurd. Criticism of the police in the news: Discourses and frames in the news media's coverage of the Norwegian bureau for the investigation of police affairs. I: Nordicom Review. 2014; Vol.35, No.1, s. 33-50, ISSN1403-1108.

Povlsen, Lene; Eklund Karlsson, Leena; Regber, Susann; Sandstig, Gabriella; Fosse, Elisabeth. Are equity aspects communicated in Nordic public health documents?. I: Scandinavian Journal of Public Health. 2014. ISSN1403-4948.

Raviola, Elena. We have never been pure: negotiations between journalism and business in newspaper organizations. I: Organizations and the media: organizing in a medialized world. red. Pallas, Josef; Strannegård, Lars; Jonsson, Stefan. Abingdon, Oxton: Routledge, 2014. s. 96-115. ISBN 978-0-415-81365-5

Roosvall, Anna. The identity politics of world news: oneness, particularity, identity and status in online slideshows. I: International Journal of Cultural Studies. 2014; Vol.17, No.1, s. 55-74, ISSN1367-8779.

Sandstig, Gabriella. Henriksen and Flora (1999) revisited: a literature review on third-person effects and children/adolescents. I: Global media researches from east to west. red. Kuyucu , Mihalis. Athens: Athens Institute for Education and Research, 2014. s. 73-92. ISBN 978-618-5065-23-2

Snickars, Pelle. Himalaya of Data. I: International Journal of Communication. 2014. (8): s. 2666-2678 ISSN1932-8036.

Snickars, Pelle; Hedling, Olof. Film Studies anno 2013: $A$ bird's eye view. I: Journal of Scandinavian Cinema. 2014; Vol.4, No.1, s. 35-41, ISSN2042-7891.

Tsani Annafari, Mohammad; Axelsson, Ann-Sofie; Bohlin, Erik. A socio-economic exploration of mobile phone service have-nots in Sweden. I: New Media and Society. 2014; Vol.16 , No.3, s. 415-433. ISSN1461-4448.

Westlund, Oscar; Bjur, Jakob. Media life of the young. I: Young. 2014; Vol.22, No.1, s. 21-41, ISSN1103-3088.

Westlund, Oscar. The production and consumption of mobile news. I: The Routledge companion to mobile media. red. Goggin, Gerard; Hjorth, Larissa. New York: Routledge, 2014. s. 135-145. ISBN 978-0-415-80947-4

Westlund, Oscar. The production and consumption of news in an age of mobile media. I: The mobile media companion. red. Goggin, Gerard; Hjort, Larissa. New York: Routledge, 2014. s. 135-145. ISBN 978-0-41580947-4

\section{www.nordicom.gu.se/en/media-research/nordicoms-databases}




\section{New Publications from Nordicom}

\section{Defending Democracy}

Nordic and GlobalDiversities in Media and Journalism

Harald Hornmoen \& Kristin Skare Orgeret (eds.) Göteborg, Nordicom, University of Gothenburg, 300 p., (21th Nordic Conference on Media and Communication Research, NordMedia, Oslo 8-11 August 2013) Nordicom Review 35(2014) August, Special Issue, ISBN 97891-86523-94-7, ISSN 1403-1108, Nordicom-Information 36(2014)2, ISBN 978-91-86523-95-4, ISSN 0349.

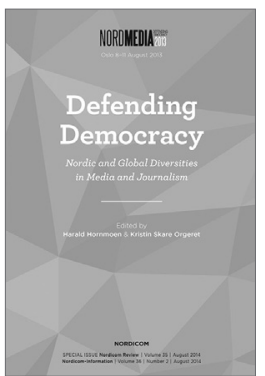

The 2013 NordMedia conference in Oslo marked the 40 years that had passed since the very first Nordic media conference. To acknowledge this 40 -years anniversary, it made sense to have a conference theme that dealt with a major and important topic: Defending Democracy. Nordic and Gloal Diversities in Media and Journalism, focusing on the relationship between journalism, other media practices and democracy.

This special issue of Nordicom Review and Nordicom Information, edited by Harald Hornmoen \& Kristin Skare Orgeret, contains the keynote speeches of Natalie Fenton, Stephen Ward and Ib Bondebjerg. A number of the conference papers have been revised and edited to become articles. Together, the articles presented should give the reader an idea of the breadth and depth of current Nordic scholarship in the area.

\section{New Wars, New Media and New War Journalism}

Professional and Legal Challenges in Conflict Reporting

Stig A. Nohrstedt \& Rune Ottosen, Göteborg, Nordicom, University of Gothenburg, 2014, 222 p. ISBN 97891-86523-96-1

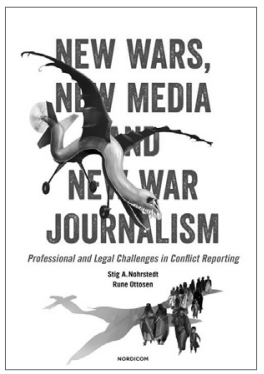

In this book, the authors discuss media coverage of major conflicts, from the Gulf War in $1990 / 91$ to the NATO military operations in Libya in 2011 and the now ongoing civil war in Syria. Through in-depth analysis of Norwegian and Swedish media coverage of the Kosovo conflict in 1999, the Afghanistan War from 2001, the Iraq War from 2003 as well as more recent conflicts, the authors claim that legal issues are poorly covered in the running news coverage of major conflicts. Underreporting of legal issues is especially problematic in relation to new forms of warfare involving extra-judicial killing by drones of targets in Pakistan, Afghanistan, Yemen and Somalia. While historically Sweden and Norway have had different security policy orientations, the tendency is toward the two countries becoming more closely oriented through Nordic defense co-operation and participation in the wars in Afghanistan and Libya.

The authors criticize mainstream media for undercommunicating what security risks this support for the regime change strategies pursued by the US/NATO in the so-called 'global war on terror' implies for the Nordic countries.

\section{Access to Information in the Nordic Countries}

A comparison of the laws of Sweden, Finland, Denmark, Norway and Iceland and international rules

Oluf Jørgensen, Göteborg, Nordicom, University of Gothenburg, 2014, 40 p. ISBN 978-91-86523-99-2. Also available as pdf, http://nordicom.gu.se

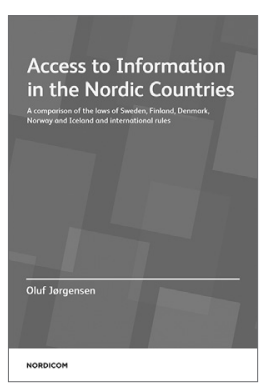

Principles of freedom of information require authorities and other public agencies to provide access to authentic documents and data. The demand for authenticity is the raison d'être of the right-of-access principle. This publication Access to Information in the Nordic Countries explains and compares the legal rules determining public access to documents and data in Sweden, Finland, Denmark, Norway, and Iceland. The publication is based on a more comprehensive version in Danish published in Nordicom-Information No 3/2014.

\section{Making Change}

Nordic Examples of Working Towards Gender Equality in the Media

Maria Edström \& Ragnhild Mølster (eds) Göteborg, Nordicom, University of Gothenburg, 2014, 240 p., ISBN: 978-91-87957-00-0.

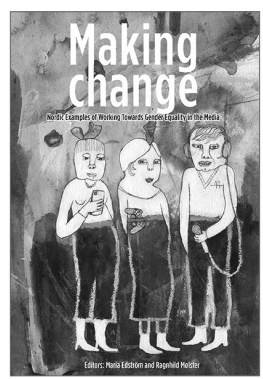

Who decides what you see on television? Which issues are important, and who gets to speak their mind in the news? How are women and men featured in texts, photos, computer games, advertising and movies? The Nordic region is well known for having gender equality as a hallmark of society. In the media sector, however, the male dominance persists 
in many areas, both in the industry itself and in the output. However, in the Nordic region there are also important examples of structural and individual steps towards gender equality in the media.

This publication presents a collection of media practices in the Nordic region and a compilation of comparative data on gender equality in the Nordic media sector (film, journalism, advertising and computer games). Contributing authors are representatives from academia, civil society, activism and industry.

\section{The Media Barometer 2013,} Special Issue: Young People and Media

Nordicom, 2014, 30 p. Available as pdf, http://nordicom. gu.se

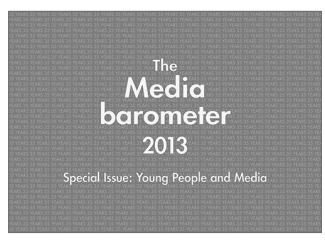

A special Media Barometer report on young people and media use. This publication is a compilation of tables and figures of the developments in the young audience's relationship to public service media, commercial channels and the internet, especially social media. The publication was presented at the EBU conference Knowledge Exchange in Stockholm October 62014.

\section{The International Clearinghouse on Children, Youth and Media}

\section{Global Citizenship in a Digital World}

Sherri Hope Culver \& Paulette Kerr (eds) Göteborg, The International Clearinghouse on Children, Youth and Media, Nordicom, University of Gothenburg, 2014, 404 p., (MILID Yearbook; 2014) ISBN 978-91-86523-97-8. Also available as pdf, http://nordicom.gu.se

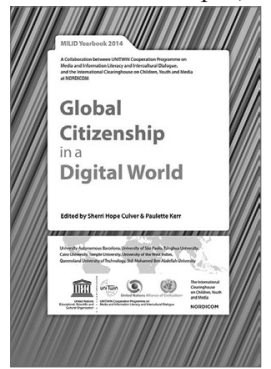

The UNITWIN Cooperation Programme on Media and Information Literacy and Intercultural Dialogue (MILID) is based on an initiative from the United Nations Educational, Scientific and Cultural Organization (UNESCO) and the UN Alliance of Civilizations (UNAoC).

The main objectives of the UNITWIN network are to foster collaboration among member universities, to build capacity in each of the countries in order to empower them to advance media and information literacy and intercultural dialogue, and to promote freedom of speech, freedom of information and the free flow of ideas and knowledge.

This second yearbook is the result of a collaboration between the UNITWIN Cooperation Programme on Media and Information Literacy and Intercultural Dialogue (MILID) and NORDICOM's International Clearinghouse on Children, Youth and Media.

\section{Young People, Media and Health Risks and Rights}

Cecilia von Feilitzen \& Johanna Stenersen (eds) Göteborg, The International Clearinghouse on Children, Youth and Media, Nordicom, University of Gothenburg, 2014, 202 p. (Clearinghouse Yearbook 2014) ISBN 97891-86523-89-3, ISSN 1651-6028.

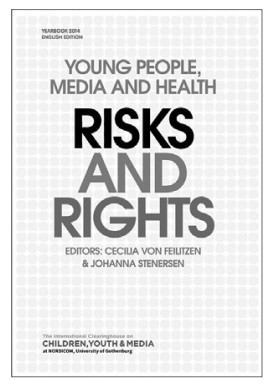

The Clearinghouse Yearbook 2014 focuses on children and young people in relation to media and health issues. Such issues represent central debates in contemporary society and pose major challenges for researchers and practitioners in a number of fields. Several contributions deal with possible risks to the health and well-being of children and young people in relation to their use of media - as viewers, listeners, readers and being on the internet - including research on how media can influence young people's physical and mental health. Other contributions treat young people's health and well-being in relation to their rights to access information, express their views and participate in the media (Articles 12, 13 and 17 in the UN Convention on the Rights of the Child). Media can, thus, also become powerful tools for participation and inclusion in groups and society.

\section{Agentes E Vozes}

Um panorama da Mídia-Educação no Brasil, Portugal e Espanha

Ilana Eleá (ed) Göteborg, The International Clearinghouse on Children, Youth and Media, Nordicom, University of Gothenburg, 2014, 202 p. (Clearinghuse Yearbook 2014 Portuguese/Spanish edition) ISBN 97891-86523-90-9, ISSN 1651-6028

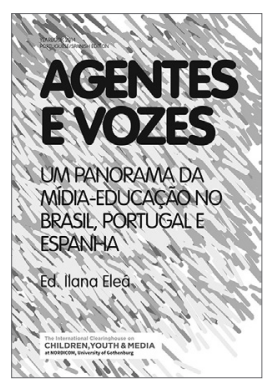

This anthology aims at contributing to the strengthening of international networks, the visibility of current research, and the exchange of experiences about strategies and challenges while promoting the field in each respective context. Despite having different cultural, economic and educational realities, Brazil, Portugal and Spain share common aspects in the field of media education encompassed by this anthology.

To facilitate the spread of information and the partnership among these countries, this is the first time that International Clearinghouse on Children, Youth and Media organizes a publication in the language spoken by its authors, Portuguese and Spanish, official languages of more than 30 countries located in Latin America, Africa and Europe. 


\section{Read More about Current Media Issues in Nordicom's Newsletters}

\author{
Media Trends \\ in the Nordic Countries \\ Newsletter from NORDICOM
}

\section{Media Trends in the Nordic Countries}

Eva Harrie (ed.) Nordicom, No 1, June 2014

The former newsletter Nordic Media Policy (2004-2012) is replaced by Media Trends in the Nordic Countries. The newsletter is gratis and can be downloaded in pdfformat. The newsletter contains reports on media developments in the Nordic region.

\section{European Media Policy \\ A Newsletter from NORDICOM}

\section{European Media Policy}

Anna Celsing (ed.) Nordicom, No 2, September, 2014.

The Newsletter provides an up-date on policy developments at the European level. From the contents in this issue: 'Google Ruling Affects Reform of EU Data Protection Rules', 'European Children's Films Sell Better Than Those for Adults', 'EU Condemns New Threats to Media Freedom in Hungary', EU Condemns New Threats to Media Freedom in Hungary'.

www.nordicom.gu.se/en/media-trends/newsletters 